\title{
Inference or Impact? Racial Profiling and the Internment's True Legacy
}

\author{
Eric L. Muller ${ }^{*}$
}

In the debate about racial and ethnic profiling in the wake of the September 11 terrorist attacks, critics of the administration's policies have frequently argued that the government has made the same fundamental error as the Roosevelt administration made when it forced 110,000 Japanese Americans into camps during World War II. This is a powerful rhetorical strategy, but is it an accurate one? What was the "fundamental error" of the Japanese American internment?

In this article, Professor Muller argues that the fundamental error of the internment was not the inference of suspicion that the government drew from the fact of Japanese ancestry, but the enormity of the deprivations that the government imposed on the basis of that inference. Seen this way, the internment recedes as a rhetorical device, which allows for a more careful and subtle debate about whether the socio-legal landscape has changed enough in the past 60 years to prevent a civil liberties tragedy like the internment from recurring. Professor Muller concludes that that landscape has not changed enough to ensure that national-origin-conscious enforcement strategies will not leap from minor to massive intrusions.

\section{INTRODUCTION: IS HISTORY REPEATING ITSELF?}

By September 10, 2001, things were looking good for the opponents of racial profiling in law enforcement. Scholars ${ }^{1}$ and the media had very effectively brought the "Driving While Black" phenomenon to the attention of policymakers and the public. And while the Supreme Court did not seem especially interested in

* George R. Ward Professor of Law, University of North Carolina School of Law. Sara Sun Beale, Joe Kennedy, Amold Loewy, Bob Mosteller, and the faculties of the Western New England College School of Law and of the Wake Forest University School of Law offered me helpful feedback on a draft of this article.

I See David A. Harris, Profiles in Injustice: Why Racial Profiling CanNot Work (2002); David A. Harris, The Stories, the Statistics, and the Law: Why "Driving While Black" Matters, 84 MinN. L. REv. 265 (1999); David A. Harris, "Driving While Black" and All Other Traffic Offenses: The Supreme Court and Pretextual Traffic Stops, 87 J. CRIM. L. \& CRIMINOLOGY 544 (1997); Katheryn K. Russell, "Driving While Black": Corollary Phenomena and Collateral Consequences, 40 B.C. L. REV. 717 (1999); Andrew Taslitz, Stories of Fourth Amendment Disrespect: From Elian to the Internment, 70 FoRDHAM L. REV. 2257 (2002); David A. Sklansky, Traffic Stops, Minority Motorists, and the Future of the Fourth Amendment, 1997 SuP. CT. REV. 271. 
curtailing the discretion of police officers to stop cars on pretextual grounds, ${ }^{2}$ elected officials from across the political spectrum condemned profiling as irrational and illegal. A justice of the New Jersey Supreme Court barely avoided an impeachment vote after it became public that he had known of and tolerated some instances of racial profiling while state attorney general. ${ }^{3}$ President Bush issued a directive ordering Attorney General John Aschroft to gather information on the "extent and nature" of "the use ... of race as a factor in conducting stops, searches, and other investigative procedures." ${ }^{4}$ Announcing the steps he was taking to implement the President's order, Ashcroft said of racial profiling, quite simply; "it's wrong."

Then, on September 11, 19 young male Arab aliens hijacked airplanes and flew them into the World Trade Center towers and the Pentagon, killing thousands of people. Among the countless impacts of that event was the unsettling of what had seemed settled about racial profiling. Here was a threat to the nation's security that came from members of a specific ethnic group-Arabs-and in the claimed name of a particular faith-Islam. Suddenly it made sense to the majority of Americans - even, if the polls could be believed, the majority of African Americans and Arab Americans - to use these features as proxies for suspicion, at least in questioning at airports. ${ }^{6}$ And the federal government began setting programs of enforcement and investigation in motion that took national origin openly into account-detaining certain aliens from Arab countries, selectively enforcing the immigration laws against some Arab aliens, and seeking investigative interviews with thousands of Arab aliens. ${ }^{7}$

The government's reaction to September 11, in turn, triggered a predictable response, of a sort that often arises when changing circumstances reshape seemingly settled law. Critics charged that by pursuing investigative and enforcement policies that took national origin into account, the government was making not only bad new rules but a bad old mistake - the mistake that led to the incarceration of 120,000 people of Japanese ancestry, or "Nikkei," during World

2 See Whren v. United States, 517 U.S. 806 (1996); Atwater v. Lago Vista, 532 U.S. 318 (2001)

3 See Wendy Ruderman, Verniero Is Spared Impeachment Vote, THE RECORD (Bergen County, NJ), April 27, 2001, at A1.

4 Memorandum for the Attorney General on Racial Profiling (Feb. 27, 2001), at http://www.whitehouse.gov/news/releases/2001/02/20010228-1.html (last visited Oct. 15, 2003).

5 Attorney General News Conference (March 1, 2001), at http://www.usdoj.gov/ag/ speeches/2001/ 030101racialprofconf.htm (n.d.).

6 See Jason L. Riley, Racial Profiling and Terrorism, WALL St. J., Oct. 24, 2001, at A22.

7 For a summary of these steps, see Natsu Taylor Saito, Will Force Trump Legality after September 11? American Jurisprudence Confronts the Rule of Law, 17 GEo. IMMIGR. L.J. 1, 1-14 (2002).

8 The word "Nikkei" is a Japanese term for Americans of Japanese ancestry, regardless of their citizenship. 
War II, and the judicial approval of much of that program in Korematsu v. United States. ${ }^{9}$ James Ridgeway put the point most explosively just a few weeks after the attacks, writing in The Village Voice that "the racial profiling that allows the government to keep tabs on [more than seven million American Muslims] may be the modern equivalent of a concentration camp." 10

This worry about legal history repeating itself is one we often see in the pages of the United States Reports at moments of change or crisis. Consider the moment in 1995 when the Court held, for the first time in nearly sixty years, that Congress had exceeded the reach of its Commerce Clause powers. " This decision, United States v. Lopez, unsettled what seemed an understanding about the Court's modest role in policing the scope of the legislative power. And the dissenters' response was to compare the majority's opinion to the most discredited decision of a bygone time: Lochner v. New York. ${ }^{12}$ According to Justice Souter, the Lopez majority's more searching scrutiny of the legislation at issue was "a backward glance at .. . the old pitfalls"13 of the Lochner era. Justice Stevens agreed, criticizing the majority's approach for "its kinship with the discredited, pre-Depression version of substantive due process" that Lochner represented. ${ }^{14}$ In a similar vein, when the Court decided in 1992 to "reaffirm" the "central holding" of Roe v. Wade ${ }^{15}$ rather than overrule it, ${ }^{16}$ Justice Scalia, in dissent, compared the decision to Chief Justice Taney's infamous opinion in the Dred Scott case. ${ }^{17}$ These are not trifling charges; Dred Scott and Lochner are two of the Supreme Court's three or four most unforgivable moments. To say that the current Court is making these particular mistakes is to accuse it not of excusable error but of dangerous amnesia.

Since September 11, allegations of amnesia have become common. "History Repeats Itself," announces the heading to a section of Professor David Cole's recent and thought-provoking article "Enemy Aliens" in the Stanford Law Review. ${ }^{18}$ Cole makes the point explicitly: "The post-9/11 response," he argues, "constitutes a reprise of some of the worst mistakes of our past."19 By "target[ing] immigrants based on their Arab identity," he asserts, the government has "fallen prey to the same kind of ethnic stereotyping that characterized the fundamental

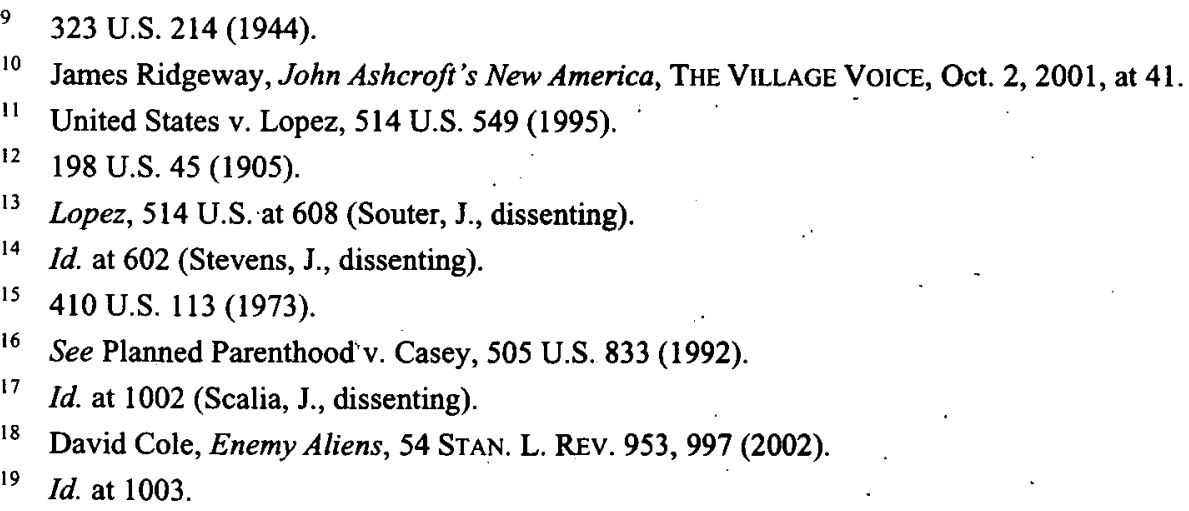


error of the Japanese internment."20 Susan M. Akram and Kevin R. Johnson put the point more forcefully, contending in a recent article that "the September 11 dragnet carried out by the federal government [against Arab and Muslim aliens] resembles the Japanese internment during World War II." current cultural response to terrorism" as "bear[ing] a great resemblance to the years and months preceding Japanese internment."22 The Yale Law Journal recently published a student note on the removal of passengers from a commercial airline flight with the title "Korematsu Continued." 23 And Laurence Tribe said it most simply of all in testimony before the Senate Judiciary Committee: "We are at the Korematsu crossroads." 24

All of this worrying about Korematsu's vitality in our post-9/11 world is, in a sense, understandable. Pearl Harbor is, after all, the clearest and most recent analogue to the attacks of September $11 .{ }^{25}$ And at the level of legal doctrine, some see a revival of Korematsu's tolerance for racial classifications in the Supreme Court's recent decisions suggesting and holding that government may take race into account in making certain sorts of decisions. ${ }^{26}$ But the worrying is also rather odd. Korematsu is a defunct decision. Eight of the nine currently sitting justices of the United States Supreme Court have called it a mistake. ${ }^{27}$ In Adarand Constructors, Inc. v. Peña, ${ }^{28}$ Justice O'Connor called the Roosevelt

20 Id. at 994; see also David Cole, The New McCarthyism: Repeating History in the War on Terrorism, 38 HARV. C.R.-C.L. L. REV. 1, 3 (2003) ("in its basic approach the government today indeed is replaying the mistakes of the past").

21 Susan M. Akram \& Kevin R. Johnson, Race, Civil Rights, and Immigration Law After September 11, 2001: The Targeting of Arabs and Muslims, 58 N.Y.U. ANN. SURV. OF AM. L. 295, 337 (2002).

22 Daniel M. Filler, Terrorism, Panic, and Pedophilia, 10 VA. J. Soc. POL'Y \& L. 345,349 (2003).

23 See Elbert Lin, Case Comment, Korematsu Continued, 112 YALE L.J. 1911 (2003).

24 Laurence Tribe, Military Tribunals Undermine the Constitution, COUNTERPUNCH (Dec. 6, 2001), available at http://www.counterpunch.org/ltribe1.html (last visited Oct. 14, 2003) (statement of Professor Tribe before the Senate Judiciary Committee).

${ }^{25}$ See generally Eric L. Muller, 12/7 and 9/11: War, Liberties, and the Lessons of History, 104 W. VA. L. REV. 571 (2002).

26 See Adarand Constructors v. Peña, 515 U.S. 200 (1995) (suggesting that strict scrutiny will not inevitably doom a facially racial classification benefiting a racial minority); Grutter v. Bollinger, 123 S. Ct. 2325 (2003) (holding that the University of Michigan Law School's admissions preference for minority applicants survived strict scrutiny). For the view that Adarand revives Korematsu, see Frank H. Wu, Profiling in the Wake of September 11: The Precedent of the Japanese American Internment, 17 CRIM. JUST. 52, 57 (2002). This view of Adarand is not well grounded, as it ignores the basic difference between race-conscious rules that burden the historically disadvantaged and those that benefit them.

27 See Muller, supra note 25 , at 586 n.80. Only Justice Souter has not gone on record as condemning Korematsu, undoubtedly because he has not yet had occasion to do so.

28515 U.S. 200 (1995). 
Administration's program an "illegitimate racial classification,"29 and the Korematsu Court's decision to uphold it an "error."30 Justices Thomas, Scalia, and Kennedy and the Chief Justice joined her. Justices Ginsburg and Breyer, dissenting in the same case, took the Korematsu Court to task for giving "a pass for an odious, gravely injurious racial classification."31 For Justice Scalia, Korematsu is not just a mistake, but a mistake on par with Dred Scott. ${ }^{32}$ It is hard to imagine a more thorough repudiation of a case than the one the Court has given Korematsu. ${ }^{33}$

Dissenting in Korematsu, Justice Robert Jackson warned that the Court's endorsement of racial discrimination in criminal procedure and of "transplanting American citizens" would "lie[ ] about like a loaded weapon ready for the hand of any authority that can bring forward a plausible claim of an urgent need." 34 This prediction has not come true, at least in the context of the government's response to the attacks of September $11 .^{35}$ But Korematsu remains a loaded weapon-a loaded rhetorical weapon, that is-for criticizing race consciousness in law enforcement. ${ }^{36}$ For some, it seems, any action that the government predicates in any way on national origin becomes not just poor policy but a replay of past outrages. Any government consciousness of national origin is, as David Cole puts

29 Id. at 236.

30 Id.

31 Id. at 275 (Ginsburg, J., dissenting).

32 See Stenberg v. Carhart, 530 U.S. 914, 953 (2000) (Scalia, J., dissenting).

33 Even the rightly reviled decision in Plessy $v$. Ferguson, 163 U.S. 537 (1896), was not so roundly criticized in Brown v. Board of Education, 347 U.S. 483 (1954), the decision that overruled it. Nowhere does the Brown Court say that Plessy was in fact wrong when it was decided; Plessy was instead based on suppositions about the psychological impact of segregation that had turned out in time to be false. See Brown, 347 U.S. at 492 ("In approaching this problem, we cannot turn the clock back to . . 1896 when Plessy v. Ferguson was written."); id. at 494 ("Whatever may have been the extent of psychological knowledge at the time of Plessy $v$. Ferguson, this finding is amply supported by modern authority."). By contrast, a majority of justices currently on the Court have made clear that Korematsu was a mistaken application of strict scrutiny when the Court decided it. See Adarand, 515 U.S. at 236 (noting that “Korematsu demonstrates vividly that even 'the most rigid scrutiny' can sometimes fail to detect an illegitimate racial classification," and that this was Korematsu's "error").

34 Korematsu, 323 U.S. at 246 (Jackson, J., dissenting).

35 See Muller, supra note 25, at 585-86.

36 See Liam Braber, Comment, Korematsu's Ghost: A Post-September IIth Analysis of Race and National Security, 47 VILL. L. REV. 451 (2002); Joel B. Grossman, The Japanese American Cases and the Vagaries of Constitutional Adjudication in Wartime: An Institutional Perspective, 19 U. HAw. L. REV. 649, 670-71 (1997); Dean Masaru Hashimoto, The Legacy of Korematsu v. United States: A Dangerous Narrative Retold, 4 ASIAN PAC. AM. L.J. 72, 89 (1996); Elizabeth M. Iglesias, Out of the Shadow: Marking Intersections in and between Asian Pacific American Critical Legal Scholarship and Latina/o Critical Legal Theory, 40 B.C. L. REV. 349 (1998); Reggie Oh \& Frank Wu, The Evolution of Race in the Law: The Supreme Court Moves from Approving Internment of Japanese Americans to Disapproving Affirmative Action for African Americans, 1 MICH. J. RACE \& L. 165, 183 (1996); Victor C. Romero, Proxies for Loyalty in Constitutional Immigration Law: Citizenship and Race after September 11, 52 DEPAUL L. REV. 871, 876-80 (2003). 
it, "the same kind of ethnic stereotyping that characterized the fundamental error of the Japanese internment.",37

This rhetorical stance therefore calls an important question for us, one that will help us to think and talk more sensibly about the use of race and national origin in investigation and enforcement after September 11: What was "the fundamental error" of the Japanese internment? ${ }^{38}$ It may seem absurd to have to think carefully about such a thing-a bit like asking one's self exactly what is tasty about ice cream or exactly what is frightening about nightmares. Most of us know, in some intuitive way, that the internment was an outrage, and that ought to be enough. But after September 11, it is not enough. Rhetoric about the internment and Korematsu hangs like a cloud over every government action that takes national origin into account in any way. Perhaps a better understanding of the "fundamental error" of the internment will offer us a better sense of what we must avoid today.

Those who see the Bush administration as repeating the error of the internment focus on the racist inference at its core. On this view, the basic mistake was to infer-from the unadorned fact of his or her ethnicity - something about the risk of subversion that a person of Japanese ancestry posed. The internment was, in other words, irrational at its core, not just in the selectivity of its suspicions (insofar as countless equally suspicious people of German and Italian ancestry went untouched), but in the very foundation of its suspicions. This account of the error of the internment dovetails nicely with the current broad condemnation of racial profiling as arbitrary.

This, however, is not the only understanding of the internment's "fundamental error." Neither is it the most obvious. One need only glance through a few wrenching photographs of the Tanforan Assembly Center ${ }^{39}$-the converted racetrack to which Fred Korematsu refused to report in the spring of 1942-in order to appreciate that the most obvious error of the internment was the enormity of the deprivation that the government imposed on the Nikkei of the West Coast. I wish to explore the possibility that the internment's "fundamental error" was the scope of its impact, rather than the inference that supported it. This refocusing of the inquiry will allow for a more nuanced understanding of the internment's true legacy for this post-September 11 world. More importantly, it will create a space within which we can consider the tragically conflicting realities that confront us: On the one hand, national origin is not an utterly arbitrary factor in all cases. But on the other hand, the government has never done well at confining itself to using that factor in a restrained and narrow way. I will conclude that we cannot yet trust

37 Cole, supra note 18 , at 994.

38 For a brief treatment of this question, see Stephen J. Ellmann, Racial Profiling and Terrorism, 19 N.Y.L.S. J. HuM. RTS. 305, 342-43 (2003).

39 See Museum of the City of San Francisco, San Francisco Evacuation, Tanforan Assembly Center and Manzanar Relocation Center Photographs (2003), available at http://www.sfmuseum.org/hist8/ppoint.html. 
our law enforcement system to use race and national origin delicately and responsibly, and that we therefore ought not allow it to use those factors at all. I reach that conclusion, however, because racial profiling today would be a mistake today-not because it would be a recurrence of the past.

\section{WHAT WAS THE JAPANESE AMERICAN INTERNMENT?}

The depressing story of the eviction and incarceration of people of Japanese ancestry in the spring and summer of 1942 has been told many times and in many formats, including fiction, ${ }^{40}$ nonfiction, ${ }^{41}$ and film. ${ }^{42}$ I have told it myself at some length. ${ }^{43}$ There might seem little to be gained from another recitation. Here, however, it is important. The debate about racial profiling since September 11 has called the important question-what exactly was the fundamental error of the Japanese American internment? Because I am exploring the idea that the fundamental error was the enormity of the deprivations imposed on the internees, some sense of those deprivations is crucial.

I note at the outset that there was more than one "internment" of people of Japanese ancestry after Pearl Harbor. In the three days following the attack, the government rounded up more than 1,500 Japanese aliens it deemed especially dangerous. The Justice Department took custody of these men and held them in enemy alien detention camps for periods of months to years. ${ }^{44}$ Separately, beginning in February of 1942, the government began to slip a tightening noose of confinement around the entire ethnically Japanese population of the West Coast, aliens and American citizens alike. It began with a dusk-to-dawn curfew and travel restrictions that forbade any person of Japanese ancestry in the affected areas

40 See, e.g., JEANNe WaKatsuki Houston \& James D. Houston, Farewell to Manzanar (1995); Marnie Mueller, The Climate of the Country (1999); Hiroshi Nakamura, Treadmill (1996); Rahna Reiko Rizzuto, Why She Left Us (1999); Danielle SteEle, Silent Honor (1996); Yoshiko UCHIDA, JoURNEY TO TOPAZ: A STORY OF THE JAPANESE AMERICAN EVACUATION (1985).

41 See, e.g., COMMISSION ON THE WARTIME RELOCATION AND INTERNMENT OF CIVILIANS, Personal Justice Denied (1997) [hereinafter Personal Justice Denied]; Roger Daniels, Prisoners Without Trial (1993); John TATEIShi, AND Justice for All (1984); Michi Weglyn, YEARS OF INFAMY (1976)

42 See, e.g., CONSCIENCE AND THE CONSTITUTION (ITVS 2000); Of CIVIL Wrongs AND RightS: THE FRED KorematSU STORY (Fournier 2000); RABbIT IN THE MOON (Wabi-Sabi Productions 1999); SNOW FALliNG ON CEDARS (Universal Studios 2000).

43 See Eric L. Muller, Free to Die for their Country (2001) (hereinafter Free to Die); Eric L. Muller, All the Themes but One, 66 U. CHI. L. REv. 1395, 1425-32 (1999); Eric L. Muller, Apologies or Apologists? Remembering the Japanese American Internment in Wyoming, 1 WYo. L. REv. 473 (2001); Eric L. Muller, The Minidoka Draft Resisters in a Federal Kangaroo Court, in NIKKEI (DIS)APPEARANCES, (Louis Fiset \& Gail Nomura eds., forthcoming 2003); Eric L. Muller, The Nisei Draft Resisters and the Constitution, in A MATTER OF CONSCIENCE: ESSAYS ON THE HEART Mountain Draft Resistance Movement 127 (Mike Mackey ed., 2002).

44 Louis Fiset chronicled the experiences of one such Japanese alien in his moving book IMPRISONED APART (1998). 
from traveling more than five miles from their homes without prior government permission. ${ }^{45}$ This program fairly quickly gave way to what was first advertised as "temporary" detention in so-called "assembly centers," most of which were hastily converted public areas - fairgrounds and racetracks - situated in or near the coast's major cities. ${ }^{46}$ In the later summer and fall of 1942 , temporary detention in the assembly centers gave way to indefinite incarceration in the ten so-called "relocation centers" in Idaho, Wyoming, Arizona, Colorado, Utah, California, and Arkansas. ${ }^{47}$ Today, when people refer to "the Japanese American internment" they typically refer to the program that culminated in the assembly and relocation centers, and I therefore focus on those. ${ }^{48}$

The initial curfew and travel restrictions were, of course, but a shadow of what was to come, and their impact on some of the Nikkei was not terribly significant. Many of the affected people were hardworking farmers and shopkeepers who had little occasion to go out in the evenings, and little reason to travel far from home. For some, however, the impact was more severe. Those who worked evenings had to choose between giving up their jobs and risking arrest. ${ }^{49}$ Truck farmers needed permission for their delivery routes; even something as routine as a dentist's appointment was bound up in red tape. ${ }^{50}$ One young Japanese American woman wrote movingly of missing the opportunity to say goodbye to her dying mother because she could not secure permission to make the emergency trip from Portland to Salem, Oregon, in time. ${ }^{51}$ Her sad experience was undoubtedly not unique.

45 See Roger Daniels, Prisoners without Trial: JAPANeSE AMericans in WORLD WAR II 53-54 (1993).

46 See Muller, supra note 43, at 28-31. Manzanar was the one assembly center that was not near a population center; it was in an area the desolation of which would later be captured by photographer Ansel Adams in a series of well-known photographs. See ANSEL ADAMS, BORN FreE AND EQUAL (2001).

47 See DANIELS, supra note 45 , at 56.

48 When people speak of the Korematsu case today, I find that they ordinarily-and erroneously - speak of the constitutionality of the government's program of indefinite incarceration in the ten relocation centers. In fact, the Korematsu Court worked hard to confine its analysis to the constitutionality only of that portion of the government's program that Fred Korematsu specifically defied: the requirement that he submit to exclusion from the military zone where his residence was. See PETER IRONS, JUSTICE AT WAR 319-25 (1983). The Court actually never passed judgment on the constitutionality of the program of indefinite detention, although it did strike that program down on non-constitutional grounds in Ex parte Endo, 323 U.S. 283, 297 (1944). For a very thoughtful analysis of Endo, see Patrick O. Gudridge, Remember Endo?, 116 HARV. L. REV. 1933 (2003).

49 As it happened, arrests for curfew violations were rare. Minoru Yasui, the American citizen who set up a test case of the legality of the curfew, paraded up and down the streets of Portland, Oregon, for hours in order to get himself arrested, and when that proved unsuccessful, he had to turn himself in at the police station and virtually demand arrest. See TATEISHI, supra note 41, at 71; IRONS, supra note 48 , at 84.

50 See MULLER, supra note 43, at 21.

51 See TATEISHI, supra note 41 , at $40-43$. 
The process of leaving home for the assembly centers was another matter entirely for the Nikkei and produced some of the most poignant moments of their entire wartime ordeal. Families typically learned the date of their so-called "evacuation"-eviction is a more accurate term ${ }^{52}$-with just ten days to two weeks notice. Because they were warned to bring with them only what they could carry, they knew that they had to get rid of just about everything they owned virtually overnight. Their white neighbors knew it too, and many swooped in to buy their soon-to-be-evicted neighbors' cars and trucks, household goods, and other valuables for just pennies on the dollar. ${ }^{53}$ Some Nikkei families found storage space for their belongings in garages and barns, only to discover upon their return at war's end that the structures had been vandalized and their goods stolen. ${ }^{54}$ Leases had to be abandoned. Produce had to be left to rot in the fields. Businesses and homes that represented decades of hard work had to be abandoned. The economic losses were simply staggering. ${ }^{55}$ Compensation for these losses, when the government finally offered it late in the $1940 \mathrm{~s}$, was negligible. ${ }^{56}$ The government offered compensation only for tangible and documentable loss of identified property, and paid only a fraction of what was claimed. One family, successful farmers before the war, could document only $\$ 1,047.85$ in losses-a fraction of their actual losses, and an even smaller fraction of the long-term impact on their earning potential and their non-economic losses-and ultimately received a check for $\$ 432.00$ from the government in settlement of their claim. ${ }^{57}$

"Evacuation" day brought the anxiety, confusion, and shame of forced and public displacement. Nobody really knew what conditions awaited them in their places of confinement. Photographs of the day show grim-faced families tagged like cattle-dazed elderly people, worried young parents, bewildered little children. Some families drove themselves to the assembly centers, their cars laden with their belongings, only to discover that they had to abandon their cars and most of their belongings at the gates. ${ }^{58}$ Few resisted, and those who did were quickly apprehended. The Denver Post of April 10, 1942, carried a story with the headline "Army Evacuates Jap Who Served 30 Years in U.S. Navy." Its first sentence captures the indignity of what the Nikkei endured:

A 67-year-old Japanese who served thirty years in the United States navy and who protested vigorously, "I'm no Jap," departed

52 An "evacuation" is a measure to protect the person being relocated, such as a homeowner in the path of an oncoming hurricane. The Nikkei were not relocated for their own protection; they were evicted to serve the interests of others.

53 See MULLER, supra note 43, at 27.

54 See Personal Justice DeniEd, supra note 41, at 122.

55 See id. at 117-33.

56 See DANIELS, supra note 45 , at 89.

57 See id. at 176-77.

58 See MULLER, supra note 43, at 27-28. 
for the Santa Anita reception center Friday under military escort. The Japanese, Isakichi Kanasawa, remained in San Diego when 1,150 others left for Santa Anita Tuesday night. Found hoeing in his garden Thursday, Kanasawa said he assumed he was exempt from the evacuation order. ${ }^{59}$

The thought of this proud and patriotic man suffering an indignity this intense is hard to endure.

Even more so is the thought of what awaited him, and the rest of the West Coast's Nikkei, when they arrived at the Santa Anita, Pomona, and Tanforan racetracks, the Puyallup fairgrounds, and the 16 other assembly centers where they would spend the summer of 1942. In the weeks after President Roosevelt issued Executive Order 9066, authorizing the military to undertake the wholesale eviction of the Nikkei from the coast, these places of amusement had been converted to places of confinement. ${ }^{60}$ Barbed wire surrounded them. Plywood guard towers sandwiched the gates and dotted the perimeter. Armed sentries manned searchlights that swept the camps at night.

Plywood barracks, hastily built for the purpose, housed as many of the displaced families as they could hold. The accommodations were spartan: four walls, army cots, and bags to fill with straw for mattresses. Communal latrines and dining halls. Dirt streets and walkways that turned to mud in the rain.

At the racetracks, the families assigned to barracks were the lucky ones. The unlucky ones ended up in the horse stalls. ${ }^{61}$ A thin layer of asphalt had been poured over the dirt to provide a floor and a barrier against the odor of horse urine. The asphalt served neither purpose well; the legs of cots easily poked through it to the filth below, and the stench was often overpowering.

For the younger United States citizens, poorly paid work was available in the assembly centers. Many of the camps produced camouflage netting and other war matériel. ${ }^{62}$ For the older aliens, on the other hand, life in the centers was enforced idleness. Contact with the outside world was difficult. White friends and neighbors who came to visit had to stand outside the barbed wire and talk to the detainees through the fences. Care packages had to be thrown over the fence, much as one might feed a wild animal. Indeed, at Santa Anita, the strip of fence where the detainees received their visitors became known as "the zoo" for just that reason. ${ }^{63}$

59 Army Evacuates Jap Who Served 30 Years in U.S. Navy, DENV. POST, April 10, 1942, at 5.

60 For a description of one assembly center and life inside it, see SANDRA C. TAYLOR, JEWEL OF THE DESERT: JAPANESE AMERICAN INTERNMENT AT TOPAZ 62-86 (1993).
61 See MULLER, FrEe to DiE, supra note 43, at 30.
62 See id. at 29
${ }^{63}$ See id. at 29-30. 
In the late summer and early fall of 1942 , the residents of the assembly centers boarded trains by the thousands for trips inland to the War Relocation Authority's ten new relocation centers. Many of the camps were still under construction as the internees arrived; indeed, at most of the camps, internee labor was essential to their completion. Most of the camps were in the high desert of the Mountain West, in spots the bleakness and desolation of which their new coastal residents had never before seen. The weather was extreme: intense heat in the summers and brutal cold in the long winters. ${ }^{64}$ In many of the camps, the wind was relentless. Summer brought swirling dust storms, while blizzards caused white-out in the winter. At the two camps in Arkansas, conditions were more swamp-like, and the mosquitoes were unbearable, as was the summer humidity. ${ }^{65}$

The barracks at the new camps were spartan too, and the internees often used spare lumber to build themselves basic pieces of furniture. ${ }^{66}$ Although the barracks had walls, they did not reach the pointed ceiling in the center of the building, which meant that noise traveled easily from unit to unit. Privacy was impossible. ${ }^{67}$

The impact on families was severe. ${ }^{68}$ Communal dining and long days of idleness led to the rapid breakdown of family structure. Teenagers broke away from their alien parents and challenged their authority in ways that would have been unthinkable outside of camp. In many families, teenaged children worked while their parents stayed idle, shifting the family dynamics still further. For a whole generation of Japanese Americans, camp delayed and disrupted school plans, and required many to abandon goals and dreams.

In 1943, the government created a form of freedom for the incarcerated Nikkei. But it was an odd form, at an odd price. The price was a willingness to attest to something that ought not to have been questioned-loyalty to the United States. This was something that the military had claimed it could not assess back in the spring of 1942 when it forced the Nikkei from their homes. But a year later, in order to facilitate the process of allowing the internees to relocate from camp to lives in the nation's interior-as well as the process of recruiting Japanese American soldiers into the United States Army-the government undertook to gauge the actual loyalty of every adult of Japanese ancestry in the camps. ${ }^{69}$ Those who passed the test (by answering "yes" to absurdly worded questions on a questionnaire) were granted "leave clearance"-that is, permission to leave camp.

64 See John Y. Tateishi, Memories from behind Barbed Wire, in LAST WITNESSES: REFLECTIONS ON THE Wartime InTERNMENT OF JaPANeSE AMERICANS 130 (Erica Harth ed., 2001); Personal JUSTICE DENIED, supra note 41, at 161.

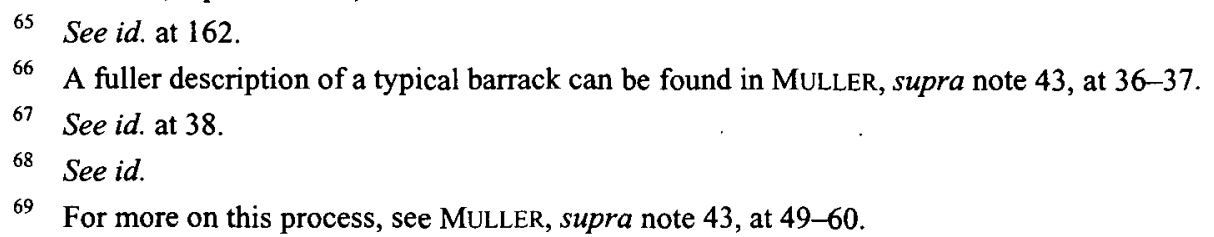


But "leave clearance" was just a euphemism for a form of parole. ${ }^{70}$ These "loyal" people were forbidden from returning to their homes, or, for that matter, to any place along the West Coast. It remained a forbidden zone of exclusion. What they were allowed to do was move further inland-so long as they could show they had a job and a place to live, and so long as they promised to keep the government apprised of their whereabouts and promised to keep away from other Japanese Americans. ${ }^{71}$ Even in freedom and certified as loyal, the Nikkei shouldered government-imposed burdens borne by no other group of Americans.

What, then, was the Japanese American internment? In a sentence, it was this: a series of government policies that imposed years of massive physical, spiritual, and economic deprivation on every man, woman, and child of a single national ancestry, without regard to citizenship, on the basis of one simple, untested inference about loyalty and potential subversion that the government drew solely from the fact of that ancestry.

\section{WHAT WAS THE "FUNDAMENTAL ERROR" OF THE JAPANESE AMERICAN INTERNMENT?}

Those who say that the administration is repeating "the fundamental error" of the Japanese American internment have a specific error in mind: the inference that was at the core of the program. Frank Wu put the point precisely in a recent article: "At heart, the internment was the association of Japanese Americans with the Japanese Empire." 72 Because that association was factually false, the argument goes, any action that the government took on the basis of it was arbitrary and illegal. To cast the point in modern terms, "living while Japanese American" was as innocent in 1942 as "driving while black" is today (and was then). This is what allows David Cole to criticize any government action targeting aliens from Arab countries as "the same kind of ethnic stereotyping that characterized the fundamental error of the Japanese internment." ${ }^{\text {"3 }}$ This view is not without support in the Supreme Court's Japanese American cases: When Justice Douglas said in Hirabayashi v. United States ${ }^{74}$ that "[d]istinctions between citizens solely because of their ancestry are by their very nature odious to a free people whose institutions are founded upon the doctrine of equality," he might have been suggesting that all race-based inferences are categorically invalid.

As to the overwhelming majority of American citizens of Japanese ancestry in 1942 , an inference of even mixed or confused loyalties was undoubtedly false.

70 See Richard Drinnon, KeEper of Concentration Camps: Dillon S. Myer and AMERICAN RACISM 52-54 (1987).

71 See id.

$72 \mathrm{Wu}$, supra note 26 , at 53-54.

73 Cole, supra note 18 , at 994.

74320 U.S. 81,100 (1943). 
This was a generation of people who had been born in this country, most of whom had never stepped foot in Japan, spoke little Japanese, and generally had no more and no less attachment to their parents' cultural heritage than would any other group of American kids with foreign-born parents. ${ }^{75}$ As to some members of a subset of this group, an inference of mixed or confused loyalties might have had some foundation: this subset was the "Kibei," American citizens whose parents sent them to Japan for their schooling. ${ }^{76}$ Some of the Kibei grew up more immersed in Japanese language and culture than American, and as to this group, it would be natural to expect some confusion about national identity when Japan and America went to war. The same is undoubtedly true for the Japanese aliens in the United States in 1942 - the immigrants who had been forbidden by racist United States naturalization law from becoming American citizens since they had arrived decades earlier. Many of these aliens considered themselves loyal Americans by the time of Pearl Harbor, even if America had never accepted them as such. ${ }^{77}$ Others surely did not.

The Japanese American internment was not, however, grounded solely on an inference about mixed, confused, or lapsed loyalty. That was just one of the inferences at the core of the program. Stacked upon it was a second inferencenamely, that a person's mixed, confused, or lapsed loyalty to the United States would make that person more likely to engage in subversive conduct that would threaten national security. And whatever foundation there may have been for doubting the loyalties of even a small subset of the Kibei in 1942, there was no foundation whatsoever for the enormous scope of what the government inferred from its doubts.

This might seem a minor distinction, but it is an important one, because it shows that the United States government's association of Japanese Americans with the Japanese empire is just one candidate for the "fundamental error" of the internment. Another candidate would be not the fact of an inference based on ancestry, but the breadth of what the government actually inferred. It is one thing to infer from the fact of a person's ancestry that he or she has mixed national loyalties, and quite another to infer that a person's national loyalties take him or her a step closer to becoming a criminal or a spy.

If one thinks past the simple fact of ancestry-based inference, other candidates for the "fundamental error" of the internment quickly emerge. Perhaps the government's basic mistake was not in the fact of its inference, but in the selectivity of its inference. German aliens and Italian aliens in the United States in 1942 were just as open to suspicion as were Japanese aliens. Indeed, many of them were more open to suspicion, because unlike the Japanese, Germans and Italians had never been barred from naturalization. This meant that many of the

75 See MULLER, supra note 43, at 8-11.

76 See Minoru Kiyota, Beyond Loyalty: The Story of A Kibei (1997).

77 Two such Japanese aliens were Iwao and Hanaye Matsushita, the couple whose wartime correspondence Louis Fiset so movingly presented in his book IMPRISONED APART, supra note 44. 
German and Italian aliens in the country in 1942 had chosen to hold on to their foreign citizenship. Yet the government inferred disloyalty only in the Japanese aliens. The same is true of the children of these immigrants. American citizens of Japanese ancestry were identically situated to American citizens of German and Italian ancestry. Yet the government inferred disloyalty only in the Japanese Americans.

Perhaps the government's basic mistake was not that it drew an inference, but that it did not cabin the inference to aliens. Every person of Japanese ancestry along the West Coast who had not yet left the zone of exclusion was subjected to the curfew, the travel restrictions, the eviction from home, the temporary detention in the assembly centers, and the indefinite detention in the relocation centers. It made no difference to the government whether the person was a citizen of Japan or a citizen of the United States. The significance of national citizenship to government decisionmaking is a much-debated topic in the literature. ${ }^{78}$ My point here is not to enter that debate. It is simply to note that if the line between citizens and aliens has meaning, it might have served as a sensible stopping-point for the inferences about loyalty and the likelihood of subversive action.

Finally, the government's basic mistake might not have been the inferences alone but the enormity of the burdens and the extent of the suffering it inflicted on the basis of those inferences. Frank $\mathrm{Wu}$ alludes to this when he notes that the internment may have been "wrong because it yield[ed] other social costs that were not properly weighted in a utilitarian calculus." 79 However, he dismisses this as an explanation of the basic wrong of the internment because he thinks that the impact of government action on marginalized groups defies measurement. "Even the suggestion that people should tolerate modest impositions is galling," he argues, because "[w] hat looks like a light touch to observers can feel like an awfully heavy hand to those who feel it." ${ }^{\prime 80}$ Naturally, people experience pain in deeply personal ways. It is potentially offensive to tell someone who is suffering that someone else is also suffering, or has suffered, more. But entire bodies of law-the Fourth Amendment's requirement that a warrantless search or seizure be "reasonable" and tort law's recognition of damages for pain and suffering come immediately to mind-are built on the notion that intrusion and suffering come in degrees. The burdens of the Japanese American internment were massive, pervasive, and lengthy. To ignore this reality in discussions about more recent episodes is to miss something crucial about this American tragedy.

In my view the Japanese American internment was wrong for all of these reasons. It was based on an untested, ungrounded, irrationally selective, and

78 For a review of this literature, see Linda Bosniak, Universal Citizenship and the Problem of Alienage, 94 Nw. U. L. REv. 963 (2000). A thoughtful treatment of the citizen-alien distinction in the post-9/11 world is Hiroshi Motomura's Immigration and We the People after September 11, 66 ALB. L. REV. 413 (2003).

$79 \mathrm{Wu}$, supra note 26, at 57.

80 Id. 
absurdly broad inference about ancestry that ignored the significance of citizenship. On that flimsy foundation it stacked structures of oppression the likes of which had not been seen since slavery and the subjugation of Native Americans. But if pressed to choose from among these mistakes the "fundamental error" of the internment-and the rhetoric of the scholarly condemnation of the current administration's policies presses such a choice-I would choose the enormity of the burdens that the internment visited upon its victims.

I justify this choice in part through a series of thought experiments. Imagine that the Roosevelt administration had retooled its policies in 1942 in order to fix one, and only one, of the problems that plagued the internment program as it actually happened. With that problem fixed, would we look back on the program today and not deem it a tragic error? Suppose, for example, that the government had "fixed" the problem of selectivity by evicting and confining not just those of Japanese ancestry, but also those of Italian and German ancestry. ${ }^{81}$ Suppose further that German American and Italian American internees had brought Korematsu-like challenges to their eviction and confinement, and that in these imaginary cases - to dramatize the point, let us call them United States v. Felix Frankfurter and In re Joe DiMaggio - the Court had upheld the program. Would we look back on this program and the Frankfurter and DiMaggio decisions and see no tragedy? Of course not.

Now suppose that the government had treated Japanese American citizens and Japanese aliens differently. That is, suppose that the government had left American citizens of Japanese ancestry alone, but had evicted the fifty-or-so thousand Japanese aliens of the West Coast from their homes and placed them in camps in desolate and inhospitable spots for the duration of the war. ${ }^{82}$ Would we look back on this episode and not see an outrage? In his book All the Laws But One ${ }^{83}$ Chief Justice Rehnquist implied that we would not; he suggested that the internment would have been tolerable if it had burdened only aliens. ${ }^{84}$ I think the Chief Justice is wrong. We might look back on an alien-only internment and see a more cabined tragedy, but we would see a tragedy nonetheless. The policy would still have been absurdly overinclusive, and the disturbing and depressing images of the camps would still haunt the public psyche. The toll in damaged and ruined lives would still have been enormous. Thus, the "fundamental error" of the internment was neither its racial selectivity nor its insensitivity to the distinction between aliens and citizens.

${ }^{81}$ Remember that this is just a thought experiment. I recognize that the Roosevelt administration would never have even contemplated such a program of across-the-board eviction and incarceration against German and Italian Americans, let alone tried to implement it. This fact alone shows the ugliness of the policies that the government did pursue.

82 Set aside, for the sake of the thought experiment, the obvious moral and logistical objections to seizing alien parents while leaving behind their citizen children.

83 See William H. ReHNQuist, All the Laws but ONe (1998).

84 Id. at 209-10. 
Now suppose that the program had not proceeded on the basis of an unadorned inference about loyalty (and an unjustified second-order inference that equated suspicion of disloyalty with suspicion of subversion). Imagine instead that the government had done what it claimed it could not do in the press of time in early 1942, and had undertaken a case-by-case inquiry of the actual loyalty of each person of Japanese ancestry and of the likelihood that each disloyal person might act on his or her allegiance to the Emperor. But then, as to each person who failed the test, suppose that the government had visited the full brunt of its suspicions, through a forcible eviction from home and multi-year confinement in a high desert internment camp. Would we look back on this smaller-scale Japanese American internment and be outraged?

This strikes me as a somewhat closer question than those I have just answered, but I believe that this episode would still have gone down in history as a tragic case. The selectivity of such a program would nag at us; we would be unable even to begin to justify the fact that people of Italian and German ancestry had never been similarly suspected, investigated, and punished. The inevitable over-inclusion of such a program would also bother us; after all, this was wartime and in these individualized assessments of loyalty and subversiveness, the government would undoubtedly have been given the benefit of any doubt. And our breaths, I think, would still be taken away by the harshness of the conditions imposed on those who failed the test.

Finally, imagine that the government had fixed that problem, by doing nothing to remove the West Coast's Nikkei from their homes, their jobs, and their schools, by causing them to lose neither income nor property, by imposing no curfew and setting up no camps. In other words, imagine that the government had just let people of Japanese ancestry along the West Coast go about their lives (much as it actually did with people of German and Italian ancestry) but had required them to answer some extra security questions before going in or near military installations, applying for a ham radio license, and buying a firearm or explosives. (Assume too-and this is a crucial assumption, as will soon become clear $^{85}$ - that the government was able to confine the impositions on people of Japanese ancestry to just these.) Would we look back on such a program and see a tragedy?

I think we would see a mistake, but nothing like the tragedy that has haunted us since the 1940s. ${ }^{86}$ And had the Court upheld such a program against constitutional challenge (as it undoubtedly would have done, in light of its ruling in the real Korematsu case), the Court's opinion would today be a useful illustration of how difficult it was for the Court to apply strict scrutiny correctly during wartime. However, it would not stand directly alongside Dred Scott, Plessy

${ }^{85}$ See infra notes 110-112, 125-143 and accompanying text.

${ }^{86}$ See Samuel R. Gross \& Debra Livingston, Racial Profiling Under Attack, 102 CoLUM. L. REV. 1413, 1424-25 (2002). 
v. Ferguson, and Lochner v. New York in the Court's Hall of Shame, as the Korematsu case does today.

\section{THE INTERNMENT AND THE RHETORIC OF TODAY'S RACIAL PROFILING DEBATE}

I believe that I have shown that, to the extent one must identify a "fundamental error" in the Japanese American internment, it was not the inference that supported the program but the staggering burdens that the program imposed on the strength of that inference. But so what? What does this tell us about the legality and wisdom of racial or ethnic profiling in today's world? What does it tell us about the government's treatment of Arab and Muslim aliens since September 11 ?

Let me first be clear about what this fundamental error of the internment does not tell us: It does not tell us that any deprivation short of years of confinement in a barren internment camp is just fine. To use the internment in this way is to commit what Frank Wu calls the "fallacy of false alternatives," in which "[a]nything short of an internment is compared to the internment, as if to say it could be worse and so there is no cause for complaint." ${ }^{.87}$ In searching for the internment's "fundamental error," and settling upon the enormity of its burdens, I do not mean to imply that the Japanese American internment sets a floor on wartime equal protection violations. I would hope and imagine instead that the internment will always be a ceiling on equal protection violations - one that no future government policy will ever come close to reaching.

What this fundamental error tells us is actually something quite modest. It simply suggests that there is a space within which we can consider the legality and wisdom of using race or ethnicity in law enforcement, without opening ourselves to the conversation-stopping charge that we are endorsing outrage. It makes the idea that race or ethnicity might sometimes be in any way relevant to law enforcement a bit less radioactive. This is, I think, a healthy contribution to open and honest debate.

Perhaps it is a measure of how far our legal culture has moved since 1944, but it is uncomfortable today to speak of race or ethnicity as a basis for any government-imposed burden. Still, this notion is one that has appeared in opinions of the Supreme Court in recent years, particularly in the writing of Justice Sandra Day O'Connor. For example, take her concurring opinion in J.E.B. v. Alabama, ${ }^{88}$ where the Court held that lawyers may not exercise peremptory challenges against prospective jurors on account of gender. Justice Blackmun's opinion for the Court derided the notion that gender might in any way predict a prospective juror's likely viewpoint. ${ }^{89}$ Justice O'Connor did not agree. "We know," she wrote, "that like

\footnotetext{
$87 \mathrm{Wu}$, supra note 26, at 57.

88511 U.S. 127 (1994).

${ }^{89}$ See id. at $138-42,146$.
} 
race, gender matters." "O0 "One need not be a sexist," she continued, "to share the intuition that in certain cases a person's gender and resulting life experience will be relevant to his or her view of the case." ${ }^{.91}$ The Equal Protection Clause, in Justice O'Connor's view, requires lawyers to set this intuition aside because the Clause creates what she calls "a special rule of relevance" 92 that takes what is intuitively and empirically relevant-a person's gender (or race) - and declares it legally irrelevant.

In the context of racial profiling, we might wish to recreate the same regime. We might wish to declare race and ethnicity to be legally impermissible grounds for any sort of suspicion in any and every circumstance. But that does not mean that they are also invariably irrelevant grounds as a matter of fact. This is especially so for what one might call "group identity crimes," in which the perpetrator expresses his racial, ethnic, or religious identity, or seeks to advance an agenda based on that identity, by committing an act of violence. ${ }^{93}$ I do not believe that the September 11 hijackers represented anything true about Islam or about what is acceptable in Arab culture and politics. But I believe that they thought they did. Al Qaeda wishes, among other things, to rid Arab lands of the presence and influence of what it considers colonialist Western governments and corrupt and godless Western culture and values. However crazed and misguided in its understanding of ethnicity and of religion, it is an Arab and an Islamist movement. And so Arab ancestry and Muslim faith are not mere statistical correlates to the threat that al Qaeda poses. They are in fact partly constitutive of the threat, in more or less the same way that the whiteness of a member of the Ku Klux Klan does not merely correlate to the threat he poses to African Americans, but in his mind actually contributes to it. Most citizens of Arab countries and most Muslims reject and repudiate al Qaeda's views. But all members of al Qaeda are Muslim, and nearly all, we are told, are citizens of Arab countries. In this post-September 11 world, it is just false to say that ethnic and religious identity do not matter. They do.

What, then, can law enforcement agents infer about any particular alien from an Arab country? As to that person's suspiciousness and likelihood to engage in terrorist acts, they can infer precious little-and probably nothing at all as to an alien who, while from an Arab country, does not fit the profile of a member of al Qaeda. For example, we might surmise that members of al Qaeda are likely to be men, reasonably young, and perhaps from specific Arab or Muslim countries.

90 Id. at 148 (O'Connor, J., concurring); see also Grutter v. Bollinger, 123 S. Ct. 2325, 2341 (2003) ("Just as growing up in a particular region or having particular professional experiences is likely to affect an individual's views, so too is one's own, unique experience of being a racial minority in a society, like our own, in which race unfortunately still matters.").

91 Id. at 149.

92 Id.; see also Brown v. North Carolina, 479 U.S. 940, $941-42$ (1986) (O'Connor, J., concurring in denial of certiorari).

93 I owe this insight to my colleague Joe Kennedy. 
(Morocco, for instance, was a country where al Qaeda was not known to operate at the time of the terrorist attacks in New York and Virginia. ${ }^{94}$ ) As a result, there was just no basis to infer anything at all about a sixty-year-old woman from Marrakesh in the weeks after September 11; there was, on the other hand, a foundation for some sort of inference, or perhaps inferences, about a twenty-five-year-old male from Saudi Arabia.

What sort of inferences? Again, not very precise ones. First, knowing nothing more about this twenty-five-year-old Saudi Arabian male, we might infer that he is more likely than a twenty-five-year-old Bolivian or Dutch male to express his religious or ethnic identity through violent acts in and against the United States. Second, we might infer that this young man knows somethingeven in entire innocence-about others who have this plan. The chance that this particular man is actually an al Qaeda terrorist is, of course, very remote; the chance that he might have some sort of useful information is also quite remote, although perhaps a bit less so.

Even in a perfect world, what actions might law enforcement officers reasonably take on the basis of these inferences? Very few. The first inferencethat the twenty-five-year-old Saudi Arabian might be a member of al Qaedamight support a few extra security questions at key locations: the United States border, airport security checkpoints, ship embarkation points, and the like. This would give the interviewing agent a bit more information about the person's itinerary and purpose in visiting the United States, and give the agent the opportunity to observe the person's demeanor in responding to the questions. The second inference-that the twenty-five-year-old Saudi Arabian might know something that would be valuable to the government's investigation of past terrorist attacks or its efforts to prevent future ones-would support a request that he sit down, at his convenience, with an investigator and answer questions about people he knows and places he has seen them. ${ }^{95}$

Certain of the administration's post-September 11 enforcement strategies made no greater use of national origin, and imposed no more burden, than this. Consider, for example, the administration's program to call in some 8,000 young male Arab aliens for investigative interviews between the end of 2001 and the first quarter of $2002 .^{96}$ This plan was quickly pilloried as impermissible racial profiling, and some local police departments refused to cooperate with the plan for

94 See United States Department of State, Countries Where al Qaeda Has Operated, available at http://usinfo.state.gov/products/pubs/terrornet/12.htm (last visited Mar. 3, 2003).

95 Samuel Gross and Debra Livingston thoughtfully explore the importance of the degree of the government's intrusion in their article Racial Profiling under Attack, supra note 86, at 1423-37.

96 See Joel Stein, The Attorney General Wants 5,000 Arabs Here to Come in for a Chat. Is This the Way to Fight Terrorism? TIME, Dec. 10, 2001, at 41 (requests for interviews of 5,000 aliens); Naftali Bendavid, Ashcroft: U.S. to Interview 3,000'More Arab Nationals, CHI. TRIB., Mar. 21, 2002, at 13 . 
that reason..$^{97}$ This criticism reflected a misunderstanding of the inference at the core of the government's program: The Bush administration was acting on an inference not that young male Arab aliens who had arrived on certain sorts of visas during a specified time period might be terrorists, but that they might be more likely than others to know terrorists, or to have information that seemed innocent to them but would be useful to investigators. And while some of the interviewees experienced the interviews as invasive, others found their interviewers to be "polite, even solicitous." program actually "yielded a new relationship between those trying to catch terrorists and the law-abiding members of the communities where the terrorists are suspected of hiding." 99

Similarly, at the start of military action against Iraq in March of 2003, the Justice Department announced a plan to seek interviews with some eleven thousand people of Iraqi descent, most of them Iraqi nationals, living in the United States. The stated purpose was to gather information about possible domestic support for Saddam Hussein's regime and to seek intelligence about Iraq that might be of use to the military. Predictably, some claimed that the program "smack[ed] of racial profiling." sure, the government selected interviewees in part on the basis of their Iraqi nationality. ${ }^{101}$ But at a time when the United States military was unleashing great violence on Iraq in order to topple its government, Iraqi nationality was not an irrational basis for investigating whether a person in the United States posed a security risk or held valuable intelligence. And when the interviews were completed, they were reported to have been "routine."102 Some found the interviews intrusive, others welcomed them, and nearly all of the interviewees

97 See Stein, supra note 96 at 41; Cole, supra note 18, at 976 (criticizing the government's interviews as illegal and unwise "group suspicion").

98 Steven Brill, The FBI Gets Religion, NEwSwEEK, Jan. 28, 2002, at 32.

99 Id.

100 Niraj Warikoo, Gathering Information: FBI Questions Iraqi Americans, DET. FREE PRESS, March 21, 2003, available at http://www.freep.com/news/nw/iraq/fbi21_20030321.htm (last visited Oct. 15, 2003) (quoting Imad Hamad, regional director of the American-Arab Anti-Discrimination Committee).

101 Notably, Iraqi nationality could have been only one of several criteria that the government used in selecting interviewees. There were estimated to be about 50,000 Iraqi nationals in the United States at the time of the war in Iraq, yet the government sought interviews with only about 11,000 of them. See Deborah Kong, FBI Questions Scores of Iraqis in U.S., A.P. ONLINE, 2003 WL 17303420 (March 28, 2003). One FBI spokesman said that the interviewing program focused on people who had recently traveled to Iraq or who had ties to the Iraqi military. See Abe Levy, Iraqi in Wichita Sees Purpose, Risks of War, WICHITA EAGLE, March 28, 2003, available at $\mathrm{http}: / / \mathrm{nl}$. newsbank.com/nl-search/we/Archives?p_action=list\&p_topdoc=91 (last visited Oct. 15 , 2003).

102 Niraj Warikoo, Mich. Iraqi Interviews Mostly Routine, Det. Free Press, Apr. 8, 2003, available at $\mathrm{http}: / / \mathrm{www}$.freep.com/news/mich/ins8_20030408.htm (last visited Oct. 15, 2003). 
conceded that the questioning was cordial and respectful. ${ }^{103}$ There might be good reasons to refuse to impose even these minimal sorts of intrusions on Arab aliens after September 11; I suggest what I think is a very powerful one below. But in this context, I do not think it helpful or accurate to say, as David Cole does, that these sorts of comparatively minor burdens reflect "the rationale used to intern 110,000 persons of Japanese ancestry during World War II." 104

Regrettably, and perhaps tellingly, however, the government has not confined its use of national origin to slight intrusions. It has instead visited significant burdens on non-citizens from Arab and Muslim countries through pretextual and sometimes openly discriminatory application of the immigration laws. In the weeks after September 11, 2001, law enforcement agents arrested hundreds of mostly Arab and Muslim aliens and held them, often for long periods and in oppressive conditions, on immigration charges that would not have been brought before the September 11 attacks or on criminal charges unrelated to terrorism. ${ }^{105}$ In mid-2002, the Immigration and Naturalization Service announced its Absconder Initiative, a program under which it would single out about 5,900 Arab and Muslim aliens for deportation from among the several hundred thousand aliens living in the United States under unexecuted final deportation orders. ${ }^{106}$ And on the first anniversary of the $9 / 11$ attacks, the INS announced a system of "special registration" 107 for certain temporary male visitors to the United States from Arab and Muslim countries. ${ }^{108}$ The program requires not just that these aliens register, but also that they sit down for at least one mandatory interview, that they keep the

103 See Curt Anderson, Interviews Here Yield Info for Battlefield, CIN. POST, 2003 WL 2914199 (March 28, 2003); Kong, supra note 101; Mark Larabee, FBI Agents Interview 400 Iraqis in Oregon, PORTLAND OREGONIAN, 2003 WL 3811074 (March 28, 2003); Ann Pepper, FBI Visiting Homes of Iraqi-Americans, ORANGE COUNTY REGISTER, 2003 WL 6990935 (March 28, 2003).

104 Cole, supra note 18 , at 976 .

105 The circumstances of these arrests and detentions were thoroughly, and critically, explored in a report filed in April of 2003 by the Justice Department's Office of the Inspector General. See Dept. of Justice, Office of the Inspector General, The September 11 Detainees: A Review of the Treatment of Aliens Held on Immigration Charges in Connection with the Investigation of the September 11 Attacks (April 2003) [hereinafter Inspector General's Report].

106 See The INS Interior Enforcement Strategy: Hearing Before the House Subcomm. On Immigration and Claims, House Committee of the Judiciary, 107th Cong. (2002) (statement of Joseph R. Greene, Asst. Comm. of Investigations, U.S. Immigration and Naturalization Service), available at http://www.immigration.gov/graphics/aboutus/congress/testimonies/2002/JGreene61902. pdf (last visited July 7, 2003); Dan Eggen \& Cheryl W. Thompson, U.S. Seeks Thousands of Fugitive Deportees, WASH. POST, Jan. 8, 2002, at A1.

107 See United States Department of Homeland Security, Special Registration: Your Portal to Information on Special Registration Procedures for Certain Nonimmigrants, available at http://www.immigration.gov/graphics/shared/lawenfor/specialreg/\#what (last visited July 7, 2003).

108 As of February 19, 2003, the special registration program had been applied to temporary visitors from Iran, Iraq, Libya, Sudan, Syria, Afghanistan, Algeria, Bahrain, Eritrea, Lebanon, Morocco, North Korea, Oman, Qatar, Somalia, Tunisia, United Arab Emirates, Yemen, Pakistan, Saudi Arabia, Bangladesh, Egypt, Indonesia, Jordan, and Kuwait. See id. 
government informed of their whereabouts, and that they enter and exit the United States through designated ports. ${ }^{109}$

These programs are more troubling than the FBI's voluntary interview program. They are all predicated on a national-origin-based inference of suspicion, and impose significant, albeit varying, burdens. To compare these programs to the Japanese American internment is, of course, still a strain: none of the programs imposes anything like the burdens imposed on the tens of thousands of Japanese Americans forced behind barbed wire. Moreover, the inference at the heart of these programs differs from the inference that supported the internment. The inference at the core of the internment was that a person of Japanese ancestry, otherwise not properly a subject of government attention, was suspicious and subject to punitive action solely because of his ancestry. The inference that supports the current programs is that a person who is already properly an object of some degree of government concern is of more urgent concern than others because he is a young male from an Arab country. Thus, it is still incorrect and unhelpful to depict these programs as a replay of the Japanese American internment. They are, in effect, bad new policy-not a horrible old one.

\section{PROFILING, ESCALATION, AND SOCIO-LEGAL LEARNING}

When we look at the Bush administration's post-September 11 policies outside the shadow of the Japanese American internment, we can distinguish a bit more carefully between programs like the FBI's voluntary interview efforts, which impose only minimal intrusions, and programs like the Absconder Initiative, which are considerably harsher. But this greater ability to sift through the government's plans does not mean that we ought to endorse those that appear minimally intrusive. Here, the Japanese American internment does provide a valuable touchstone for analysis. That historical episode teaches us not that any nationalorigin-based inference of suspicion is irrational, but that it might be nearly impossible for us to cabin state-sponsored discrimination to minor intrusions.

It is important to remember that in a period of about six months in 1942 , the impositions on Japanese Americans spiraled from a dusk-to-dawn curfew, to temporary detention in assembly centers, to full-blown and indefinite incarceration in internment camps. While obviously far milder in its methods and its outcome, the Japanese American internment followed the pattern of escalating burdens that marked the Nazi government's treatment of German Jews: what began as comparatively minor impositions in the mid-1930s turned into out-and-out genocide by the early 1940 s. ${ }^{110}$

\footnotetext{
109 See id.

110 For a chilling, first-person account of these escalating impositions, see VIKTOR KLEMPERER, I WILL BEAR WITNESS: A DIARY OF THE NAZI YEARS 1933-1941 (1998) and VIKTOR KLEMPERER, I WILL BEAR WITNESS: A DIARY OF THE NAZI YEARS 1942-1945 (1999).
} 
This pattern of escalation may be no historical accident: it is possible that governments have a hard time confining themselves to just a little bit of raceconscious suspicion, especially in times of conflict and crisis, and that government agents who are told that they may take race and ethnicity into account for very minor intrusions cannot be trusted to confine themselves to that standard. There is always a chasm between the legal standards that are supposed to govern the conduct of law enforcement officers and the ways in which those officers actually behave. Miranda y. Arizona may be the law, but police officers routinely violate it, sometimes after being trained to do so. ${ }^{11}$ Similarly, scholars have documented that many police officers are willing to violate the known Fourth Amendment rights of suspects. ${ }^{112}$ Thus, when given an inch in the area of racial profiling, some officers will be tempted to take a mile.

If it is correct that burdens imposed on account of race or national origin tend to escalate, then the important question for us to address as we consider racial profiling after September 11 is not whether a particular government action relies on the same inference that supported the Japanese American internment. The question is whether more structures are in place today to confine that government action to genuinely minor intrusions. Is the legal landscape as open today as it was sixty years ago to the wildfire-like spread of race- and ethnicity-based programs to greater and greater deprivations? Or, have firebreaks appeared in the last sixty years to keep the blaze from spreading?

No one has sufficient distance from this historical moment to make such a judgment reliably. Surely the American socio-legal landscape has undergone important changes in the past sixty years-changes that might do something to keep the scope and impact of race- and ethnicity-conscious programs in check. There is, first and foremost, the experience of the Japanese American internment itself, and the recognition that it was a huge and tragic mistake. I noted earlier that eight of the nine sitting Justices have repudiated the Korematsu decision, but perhaps more importantly, the political branches of the federal government clearly repudiated the entire program during the 1980s. After thoroughly investigating the causes and methods of the Roosevelt administration's wartime program, ${ }^{113}$ the Congress passed legislation in 1988 that apologized to the surviving internees for the "grave injustice [that] was done to both citizens and permanent residents of Japanese ancestry by the evacuation, relocation, and internment of civilians during World War II," and the "enormous damages, both material and intangible, and [the] ... incalculable losses in education and job training, all of which resulted in

III See Charles D. Weisselberg, In the Stationhouse after Dickerson, 99 MicH. L. REV. 1121, 1135-54 (2001); Charles D. Weisselberg, Saving Miranda, 84 CoRNell L. REV. 109 (1998).

112 See William C. Heffernan \& Richard W. Lovely, Evaluating the Fourth Amendment Exclusionary Rule: The Problem of Police Compliance with the Law, 24 U. МiCH. J.L. REFORM 311, 345-55 (1991).

113 The results of the investigation by the congressionally created Commission on Wartime Relocation and Internment of Civilians are summarized in the excellent volume PERSONAL JUSTICE DENIED, supra note 41. 
significant human suffering." 114 The legislation also awarded a token redress payment of $\$ 20,000$ to each surviving internee. ${ }^{115}$ Public awareness of the tragedy of the internment has increased as well, with the mass-market circulation of the book Snow Falling on Cedars and its big-screen version, ${ }^{116}$ the creation of museums and memorials such as the Japanese American National Museum in Los Angeles and the National Japanese American Memorial to Patriotism in World War II in Washington, D.C., the permanent exhibit on the internment at the National Museum of American History, and the appointment of former internee Norman Mineta to the Cabinet of the Bush Administration.

It is also worth noting that American equal protection law has developed since World War II in the constant shadow of the Holocaust and its genocidal use of inferences about the suspiciousness of Jews and others. To be sure, the example of the Holocaust has not precluded other genocides; the images of ethnic cleansing in the former Yugoslavia and the slaughters in Rwanda are still tragically clear in our minds. But in the American context, the Holocaust has played an important, if often unobserved, role in reminding us of the extraordinary violence that can lie at the end of the path of racial stereotyping.

Against the backdrop of the internment and the Holocaust, a remarkable story of legal and social transformation has played itself out over the past sixty years. I do not mean to suggest that the story has been a constant upward spiral of achievement or that difficult problems do not remain. But the progress has been significant. Ten years after Korematsu, in Brown v. Board of Education, ${ }^{117}$ the United States Supreme Court launched the federal courts on the project of dismantling the entrenched system of racial apartheid that still thrived in much of the southern United States. Along with this came the development of strict judicial scrutiny of all racial line-drawing that burdens racial minorities, a test so rigorous that no government action (since the Japanese American internment itself) has survived it. ${ }^{118}$

114 Civil Liberties Act of 1988,50 U.S.C. app. $\$ \S 1989 b-b-9$ (2000).

115 See id.

116 SNOw Falling ON Cedars, supra note 42.

117347 U.S. 483 (1954).

118 I do not address in this article the knotty doctrinal problem of whether a program that allows a government agent to take action on the basis of a suspect's national origin could ever survive strict scrutiny under the Equal Protection Clause. This is a question that Albert Alschuler has recently addressed in detail. See Albert Alschuler, Racial Profiling and the Constitution, 2002 U. CHI. LEGAL F. 163 (2002). I do, however, find some initial appeal in the idea that, to the extent that strict scrutiny leaves any space at all for race- or ethnicity-conscious investigation, the Fourth Amendment might provide some guidance on how that space should be regulated. The Fourth Amendment requires that a warrantless search or seizure be "reasonable," and the inquiry into reasonableness often focuses on how intrusive the government's action is. See Terry v. Ohio, 392 U.S. 1, 18 (1968). This is an idea that George Thomas has tentatively, and usefully, explored. See George C. Thomas, III, Race, Terrorism, and a New Approach to Consent Searches, 73 MISs. L.J. (forthcoming 2004) (on file with author). 
The Brown decision was followed by a decade of often stunning progress on matters of race discrimination, much of which emerged from the political process, rather than from the courts. The various civil rights acts and amendments of the Kennedy and Johnson administrations envisioned and worked toward the racial integration of the American workplace and of places of public accommodation, and an entire administrative apparatus was set up to enforce those laws. ${ }^{119}$ The military confronted its segregationist past and integrated with remarkable success. ${ }^{120}$ Minority representation in state and federal legislatures and the courts increased significantly. African Americans have also come to occupy positions of great power in the federal executive branch. ${ }^{121}$ (And so too, notably, have Americans of Japanese ${ }^{122}$ and $\mathrm{Arab}^{123}$ ancestry.)

Important changes in the meaning and significance of race have occurred at the grassroots level as well. The various racial, ethnic, and gender movements of the 1960s and 1970s transformed the ways in which historically disadvantaged groups conceived of themselves and presented themselves to the larger population. Movements for racial, ethnic, and gender pride and advocacy first became thinkable, and then became common, among historically disadvantaged groups.

Seen in this light, the pre-September 11 consensus on the evils of racial profiling was no accident; it was the culmination of several decades of change in the public's understanding of the relevance of race in law enforcement and, more generally, in discourse on public policy. The explicit imposition of burdens on the basis of race, which had been the nation's largely unapologetic practice for its first one hundred sixty or so years, moved from the center of the debate to the fringes. To use a variant of a phrase that Mark Tushnet has used in a related context, I would argue that American society and its legal system have had six decades of "socio-legal learning" ${ }^{24}$ on the ugliness and the dangers of race-based government action. The lessons learned have not been unambiguous, and not all of us have studied them as hard as we might. But the lessons are certainly not incoherent.

On the other hand, however, there are plenty of reasons to worry that time has not created sufficient firebreaks in the legal landscape to keep the flame of minimal race- or ethnicity-based intrusions from blazing out of control. First, and

119 See Hugh Davis Graham, The Civil Rights ERa: Origins and Development of National POLICY 1960-1972 (1990).

120 See Morris J. MacGregor, JR., INTEgration OF THE ARMEd ForCES, 1940-1965 (1981).

121 In the current administration, both the Secretary of State (Colin Powell) and the National Security Advisor (Condoleezza Rice) are African American.

${ }_{122}$ Norman Mineta, a former internee, is now the Secretary of Transportation in the Bush Administration. Eric Shinseki is the Chief of Staff of the U.S. Army.

${ }^{123}$ Spencer Abraham, the grandson of Lebanese immigrants, is now the Secretary of Energy, and John Sununu, also of Lebanese ancestry, was the first President Bush's Chief of Staff.

124 See Mark Tushnet, Defending Korematsu? Reflections on Civil Liberties in Wartime, 2003 WIS. L. REV. 273. Robert M. Chesney's discussion of "adaptive learning" is also quite helpful in this connection. See Robert M. Chesney, Book Review, Civil Liberties and the Terrorism Prevention Paradigm: The Guilt by Association Critique, $102 \mathrm{MiCH}$. L. REV. (forthcoming 2003). 
perhaps most importantly, people in positions of power too often seem to have missed the last sixty years' worth of social learning. In a single week in February of 2003, two Members of Congress from my home state of North Carolina went public with simply extraordinary views on the Japanese American internment and on the suspiciousness of Arab Americans. Fielding questions after a speech on terrorism at the Heritage Foundation, Representative Sue Myrick spoke about dangers within the country. She said, "You know, and this can be misconstrued, but honest to goodness [my husband] Ed and I for years, for 20 years, have been saying, 'You know, look at who runs all the convenience stores across the country.' Every little town you go into, you know?"125 Not to be outdone, Representative Howard Coble, speaking on a radio talk show a few days later, volunteered that he supported Franklin Roosevelt's policy of internment for Japanese Americans during World War II. Trotting out a long-discredited rationale for the internment, Coble added that "[f]or many of these Japanese Americans, it wasn't safe for them to be out on the street." 126 In other words, Japanese Americans were imprisoned for their own good. Representative Coble is the Chairman of the House Judiciary Subcommittee on Crime, Terrorism, and Homeland Security, the committee with primary oversight of the new Department of Homeland Security. I would not trust him or Representative Myrick to police the line between minimal and severe race- and ethnicity-based government actions.

In addition, while it is true that the larger legal landscape has changed significantly in the last sixty years, the changes have come more slowly at the level of actual police-citizen interactions-precisely the spot where many race- and ethnicity-based intrusions are most likely to occur. The Supreme Court has shown decidedly little interest in scrutinizing the motivations of police officers when they make stops, ask questions, and perform frisks and searches. ${ }^{127}$ The Supreme Court has also removed or watered down many of the incentives for police compliance with its rules on criminal investigations, with the result that actual police conduct in the field may be more intrusive than what "the law" officially allows. ${ }^{128}$

More importantly, most interactions between law enforcement agents and citizens happen outside of public scrutiny, and therefore largely outside of public accountability. The government has insisted on secrecy in as many of its postSeptember 11 dealings as possible, including immigration hearings, where allegations of excess might be heard and tested. ${ }^{129}$ And in any case, law enforcement officers benefit from the rich doctrine of good-faith immunity from

125 Jim Morrill, Coble, Myrick Face Heat for Comments, ChaRlotte OBSERver, Feb. 6, 2003, available at $\mathrm{http}: / / \mathrm{www} . c h a r l o t t e . c o m / \mathrm{mld} / \mathrm{observer} /$ news $/ \mathrm{local} / 5117163$ htm (last ${ }^{-}$visited Mar. 3, 2003).

126 Id.

127 See, e.g., Whren v. United States, 517 U.S. 806 (1996).

${ }^{128}$ See Carol S. Steiker, Counter-Revolution in Constitutional Criminal Procedure? Two Audiences, Two Answers, 94 MICH. L. REV. 2466, 2533-49 (1996).

129 See Lincoln Caplan, Secret Affairs, 1 LEgAL AFF. 1, 1 (2002). 
constitutional tort liability that the courts have created and strengthened for them over several decades. ${ }^{130}$ Thus, to the extent that we would expect the scrutiny of an energetic press and a curious public to serve as a firebreak, there will be a good deal less of that than is likely necessary.

These are, moreover, risks on which we do not need to speculate. In April of 2003, the Justice Department's Office of the Inspector General made public a report on the treatment of aliens held on immigration charges in connection with the investigation of the September 11 attacks. ${ }^{131}$ It is a depressing document. Seven hundred sixty-two aliens, almost exclusively Arab and Muslim, ${ }^{132}$ were arrested, mostly on immigration charges, between September of 2001 and July of $2002 .{ }^{133}$ Many of these aliens came under suspicion primarily because of their national origin. ${ }^{134}$ Yet the suspicion hardly led to just minimal intrusions. They led rather to an almost Kafka-esque series of escalating burdens, all imposed by a law enforcement and corrections system that did not seem interested in drawing distinctions among the aliens or protecting their rights.

First, and perhaps most notably, the aliens were not simply questioned or watched; they were arrested and detained. Once it arrested them, the FBI made little effort to distinguish between those who were subjects of an actual terrorism investigation and those who were detained solely for immigration violations. ${ }^{135}$ The Immigration and Naturalization Service ("INS") routinely failed to serve the detainees with timely notices of the charges under which it was holding them. ${ }^{136}$ And the Justice Department decided that no detainee who was "of interest" to the FBI in relation to terrorism - an exceedingly loosely defined category - could be released from custody until first "cleared" of terrorism suspicion. ${ }^{137}$ The clearance process took an average of eighty days, far longer than the "few days" that the Justice Department had anticipated. ${ }^{138}$ Justice Department officials knew of these delays, but did nothing. ${ }^{139}$

The burdens on the September 11 detainees did not end there. The INS adopted a blanket policy of refusing them release on bond, and supported this policy with boilerplate affidavits that recited general national security concerns but averred nothing specific to any individual detainee's case. ${ }^{140}$ And this "no bond"

${ }^{130}$ See generally Alan K. Chen, The Ultimate Standard: Qualified Immunity in the Age of Constitutional Balancing Tests, 81 IowA L. REV. 261 (1995).

131 See Inspector General's Report, supra note 105.

132 See id. at 21.

133 See id. at 22-23.

${ }^{134}$ See id. at $15-17$.

135 See id. at $37-50$.

136 See id. at $29-35$.

137 See id. at 37-43.

138 See id. at 51.

139 See id. at 65-66.

140 See id. at 76-79. 
policy kept the detainees locked up in conditions that were, in many cases, horrifying. For several weeks after September 11, they were completely cut off from the outside world, under a total communications blackout. ${ }^{141}$ Once allowed contact with the outside world, the contact was spotty and difficult to obtain, even with legal counsel. ${ }^{142}$ Perhaps most disturbingly, many of the September 11 detainees were subject to a pattern of physical and verbal abuse by some correctional officers, including name-calling, excessive physical force and restraint, twenty-four-hour-per-day exposure to fluorescent light, and inadequate medical treatment and recreation. ${ }^{143}$ In the few months after the horror of September 11, the flame of discrimination simply jumped the firebreaks in the legal landscape that were supposed to control it.

\section{CONCLUSION: THE INTERNMENT'S ROLE IN THE PROFILING DEBATE}

In the final analysis, we are not yet ready to authorize law enforcement agents to use a person's race or ethnicity in assessing their potential dangerousness. The legal landscape has changed since World War II, but racial law enforcement has always tended to spread like wildfire, and the firebreaks we have built are still too few and too narrow to contain it. Perhaps a time will come when we have confidence that public attitudes and our legal system are up to the task of confining the use of race and ethnicity to only the most minor of intrusions in cases of great need. I do not believe that today is that time.

Today is the time, however, to step out a bit from the shadow of Korematsu and the Japanese American internment in our discussion. The internment does not reflect the proposition that many opponents of racial profiling would like to attribute to it. It does not embody the principle that any race- or ethnicity-based inference about a person's suspiciousness is invalid and unlawful. What it does embody is a sort of outer limit: the government may not impose significant burdens on people on the strength of such an inference. Thus, a moment when the government is asking certain young male Arab aliens to appear for informationgathering interviews is not a moment to invoke the legacy of the internment and Korematsu. That does nothing to stimulate careful thinking about the legality of such a program.

By stepping out from the shadow of the internment, and recognizing that its fundamental error was the enormity of its deprivations, we open up a bit of space for a more reasoned and realistic debate about racial profiling in the world in which we live today. If we conclude - as I think we should - that profiling is bad policy for us today, we will reach that conclusion with our eyes open to the twin realities that profiling might sometimes be rational and that profiling very likely

\footnotetext{
141 See id. at 112-14.

142 See id. at $130-41$.

143 See id. at 142-64
} 
will get out of hand. The internment, of course, plays the important role of reminding us of how ugly profiling is when it gets out of hand. But it is only that $-\mathrm{a}$ reminder. It is not always history about to repeat itself. 
